Research Article

\title{
Identification of Potential Pathogen Bacteria Causing Tuber Rot in Porang (Amorphophallus muelleri Blume)
}

\author{
Afifah Nur Aini, Rodiyati Azrianingsih *, Irfan Mustofa \\ Department of Biology, University of Brawijaya, Malang 65145, Indonesia
}

Article history:

Submission April 2019

Revised August 2019

Accepted November 2019

*Corresponding author:

E-mail: rodiyati@ub.ac.id

\begin{abstract}
Tuber rot has been reported as one of the limiting factors to porang (Amorphophallus muelleri Blume) tuber production. Bacterial infection is one of the main causes of tuber rot during storage. In this study, a total of seven bacterial isolates obtained from porang tubers were tested for their potency to cause rotting on porang tubers. Porang tubers were immersed in bacterial suspension and incubated for 14 days. The physical properties of the tubers such as texture and color, and the chemical properties such as reducing sugar and ethanol content were determined at the end of incubation period. All infected tubers were soft, slimy and darker. Two isolates, T4 and T9A, had the highest potency to cause tuber rot indicated by the significantly higher reducing sugar content (14.38 and 15.32 $\mathrm{mg} / \mathrm{ml}$ ) and higher ethanol content (32.17 and 35.05\%) compared to control tubers which were not infected with bacteria. Both isolates were identified as Bacillus altitudinis and Pseudomonas stutzeri, respectively, based on 16S rDNA sequence analysis.
\end{abstract}

Keywords: Amorphophallus muelleri, pathogen bacteria, tuber rot, porang

\section{Introduction}

Porang (Amorphophallus muelleri Blume) is a perennial tuberous herb belonging to the Araceae family. A. muelleri tuber is rich in glucomannan (up to $70 \%$ ) [1], a polysaccharide with many industrial uses and health benefits. This property makes porang tuber a valuable commodity. Every year, Indonesia exports around 300 tons of porang dried chips to Japan, China and Korea [2].

The tuber production, however, is hindered by the decreasing quality and quantity of tubers due to tuber rot. Freshly harvested porang tuber has high water content (75-87\%) [3], which provides a favorable environment for the growth of rotcausing microorganisms. The climate in Indonesia which has warm temperature and high humidity is stated to have a role in promoting soft rot disease [4].

Some of the bacteria that have been reported as the cause of tuber rot (also known as soft rot bacteria) in Amorphophallus spp. are Pectobacterium chrysanthemi [5], Dickeya dadantii [6], and sometimes saprophytic bacteria such as Bacillus, Pseudomonas and Clostridium spp. [7]. Bacterial infection of tubers occurs through the wound caused by harvesting or insect bites.

Tubers infected with soft rot bacteria undergo physical and chemical changes. The rotting tubers become soft and slimy, change color from yellow to dark brown or black, and emit an unpleasant smell [4]. The severity of soft rot disease had a positive correlation with the relative total sugars and reducing sugars in potatoes [4]. Volatile metabolites, such as methanol, ethanol, propanol and butanol, were produced higher in potatoes that are infected with soft rot bacteria than in healthy ones [8].

Exploration of new pathogen species is important because the information will be useful in determining tuber rot control methods and improving the quality and quantity of tuber. Therefore, this study is intended to determine the bacteria isolated from porang tuber that have the high- 
est potency to cause rotting using physical and chemical properties of the tuber as parameters and to identify it based on $16 \mathrm{~S}$ rDNA sequence.

\section{Material and Methods}

There is a total of seven bacterial isolates that were obtained from the collection of Microbiology Laboratory, Faculty of Mathematics and Natural Sciences, University of Brawijaya. The isolates were originally isolated by previous researchers from porang tubers cultivated in Rejosari Village, Bantur, Malang. The isolation was done during storage period of porang tubers.

\section{Bacterial culture preparation}

Bacterial isolates were sub-cultured using streak and spread method on NA (Nutrient Agar) media and incubated at $30^{\circ} \mathrm{C}$ for $24 \mathrm{~h}$. The isolates were purified based on colony morphology and confirmed with Gram staining. If different colonies were found, re-purification was carried out until single colony was obtained. The isolates were cultured on slant agars and stored at $4^{\circ} \mathrm{C}$ for future needs [9].

\section{Pathogenicity test}

Pathogenicity test was based on Koch's Postulate principle. Each isolate was cultured in NB (Nutrient Broth) media at $30^{\circ} \mathrm{C}$ for $24 \mathrm{~h}$. After the cell density of each culture was equalized, bacterial suspension was made by inoculating $2 \mathrm{ml}$ of bacterial culture into $20 \mathrm{ml}$ of sterile NB in a culture bottle closed with cotton plug. Porang tuber slices were surface-sterilized by soaking in $5 \%$ $\mathrm{NaOCl}$ for two minutes and rinsing with sterile water for one minute twice [10]. The tuber slices (triplicate) were immersed in the prepared bacterial suspension of each isolate and incubated at $30^{\circ} \mathrm{C}$ for 14 days [11]. At the end of incubation period, each tuber slice was taken out of the suspension and put in a Petri dish to observe the color Sample Preparation for Tuber Chemical Assays

Each tested tuber slice ( $2 \mathrm{~g}$ ) was thoroughly pulverized in a mortar and put in a centrifuge tube. The bacterial suspension $(10 \mathrm{ml})$ from which the tuber slice was taken was added into the same tube. The mixture was centrifuged at $5.000 \mathrm{rpm}$, $10^{\circ} \mathrm{C}$ for 10 minutes. Supernatant was used for the determination of reducing sugar and ethanol content.

\section{Reducing sugar assay}

Reducing sugar content in tuber was determined using spectrophotometric method [12]. The prepared supernatant $(1.5 \mathrm{ml})$ was added with 1.5 $\mathrm{ml}$ of distilled water and $3 \mathrm{ml}$ of DNS (dinitrosalicylic acid) reagent in a test tube. The mixture was vortexed and heated in a waterbath at $90^{\circ} \mathrm{C}$ for 10 minutes. After the mixture was cooled down, $1 \mathrm{ml}$ of $40 \%$ Rochelle salt solution was added. The absorbance of the mixture was measured at $540 \mathrm{~nm}$. Reducing sugar content was calculated from a standard curve made by using 2.5, 5, 7.5, 10, 12.5 and $15 \mathrm{mg} / \mathrm{ml}$ glucose solution.

\section{Ethanol assay}

Ethanol content in tuber was determined using spectrophotometric method [13]. The prepared supernatant $(3 \mathrm{ml})$ was added with $1.5 \mathrm{ml}$ of potassium dichromate $\left(\mathrm{K}_{2} \mathrm{Cr}_{2} \mathrm{O}_{7}\right)$ reagent in a capped test tube. The absorbance of the mixture was measured at $595 \mathrm{~nm}$. Ethanol content was calculated from a standard curve made by using $2.5,5$, 7.5, 10, 12.5 and $15 \%$ ethanol.

\section{Data analysis}

The data from tuber chemical assays were analyzed with One Way Analysis of Variance (ANOVA) using IBM SPSS Statistics 20 program. Significant difference is indicated with p-value less than 0.05 .

\section{Bacterial identification}

The isolate with the highest potency to cause rotting was selected for molecular identification. Bacterial DNA was extracted following the protocol from Zymo Research's Quick-DNA ${ }^{\mathrm{TM}}$ Miniprep Kit. The 16S rDNA sequence was amplified by PCR using the conserved primers 27f (5'AGAGTTTGATCCTGGCTAG-3') and 1492r (5'-CTACGGCTACCTTGTTACGA-3'). PCR thermal conditions were as follows: predenaturation at $94^{\circ} \mathrm{C}$ for $5 \mathrm{~min}$, denaturation at $94^{\circ} \mathrm{C}$ for $30 \mathrm{~s}$, annealing at $55^{\circ} \mathrm{C}$ for $30 \mathrm{~s}$, extension at $72^{\circ} \mathrm{C}$ for $90 \mathrm{~s}$ and post extension at $72^{\circ} \mathrm{C}$ for $5 \mathrm{~min}$ [14]. Forward and reverse strands of the amplified DNA fragment were sequenced in an Automatic Squencer Analyzer ABI 3130 sequencer (1st Base, Malaysia). The forward and reverse sequences were edited using Sequence Scanner v1.0 program and combined using BioEdit v7.2.5 program. The 


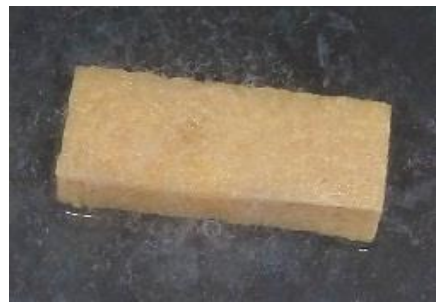

(a)

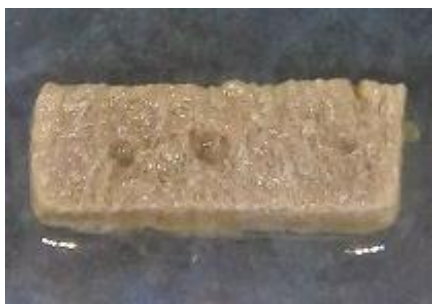

(b)

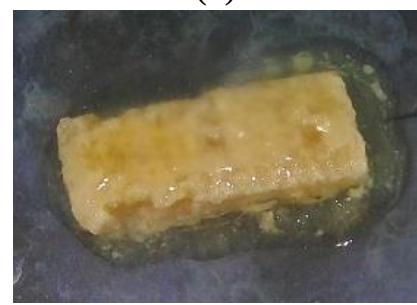

(c)

Figure 1. The condition of tubers after 14 days of incubation. Control tuber (a) and tuber infected with bacterial isolate T4 (b) and T9A (c).

$16 \mathrm{~S}$ rDNA sequence of the isolate was aligned together with reference 16S rDNA sequences obtained from NCBI database. The phylogenetic tree was constructed using MEGA 6.00 program [15].

\section{Results and Discussions \\ Pathogenicity of bacterial isolates on porang tubers}

A total of seven isolates from laboratory collection were tested for the potency to cause rotting on porang tubers. Each isolate was shown to have pathogenic properties based on the physical parameters. There were texture and color changes in tubers infected with bacteria and control tuber which was not infected with bacteria.

After 14 days of incubation, all tubers infected with bacteria had soft and slimy texture and darker color, while the control tubers had rigid texture and light-yellow color. The most notable changes were observed in tubers infected with isolate T4 and T9A in which the texture was the softest and the color changed into brownish yellow and light brown (Figure 1).

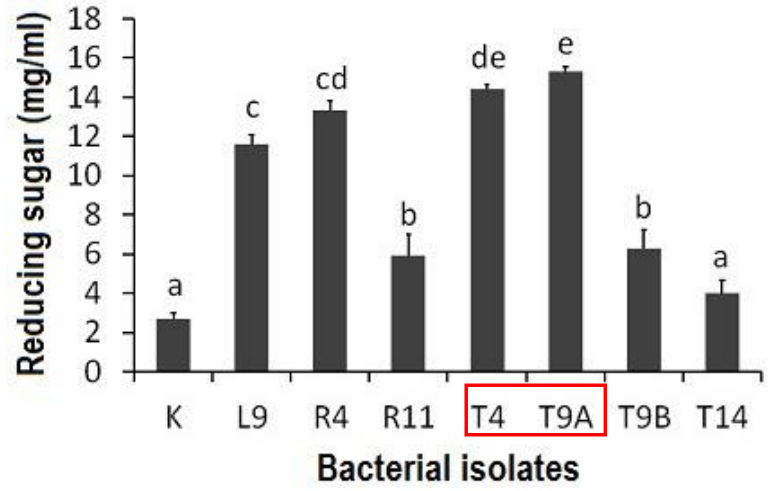

Figure 2. Reducing sugar in tubers infected with bacterial isolates after 14 days of incubation

The texture change in rotting tuber is related to the tissue maceration caused by the pectinolytic enzymes secreted by pathogenic bacteria. Soft rot bacteria secreted pectinolytic enzymes that break down pectin in the middle lamella, that acts as connector between cells and gives rigidity [16]. The pectinolytic enzymes include pectinases, cellulases, proteases, and xylanases [7]. The color change in rotting tuber due to necrosis. After the cell wall components degrade, the dead tissue will dry up and turn color into light brown or beige [17].

Despite the physical properties of all infected tubers showing symptoms of rotting, the pathogenicity of bacterial isolates should also be determined by their ability to alter the chemical contents in tuber. The reducing sugar and ethanol assay of tuber was done after 14 days of incubation. Based on the reducing sugar assay, there were two isolates showing the highest reducing sugar content out of all tubers tested (Figure 2). The reducing sugar content in tubers infected with isolate T4 and T9A were 14.38 and $15.32 \mathrm{mg} / \mathrm{ml}$, respectively. These two isolates were not statistically different, but the difference between them and the other isolates was significant $(p<0.05)$.

Isolate T4 ad T9A also had the highest ethanol content out of all tubers tested in the ethanol assay with ethanol percentage of 32.17 and $35.05 \%$, respectively (Figure 3). There was no significant difference between these two isolates, but they were statistically higher than the other isolates ( $<$ < 0.05). Based on these results, isolate T4 and T9A were selected as the potential pathogen bacteria with the highest potency to cause rotting on porang tuber. 


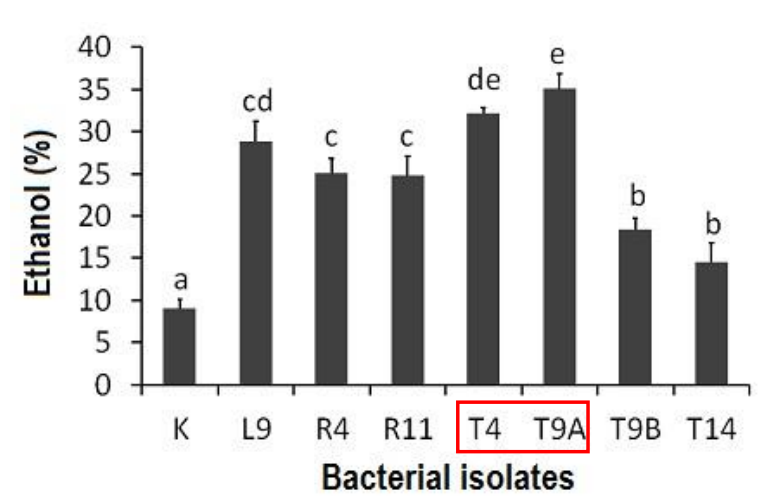

Figure 3. Ethanol in tubers infected with bacterial isolates after 14 days of incubation.

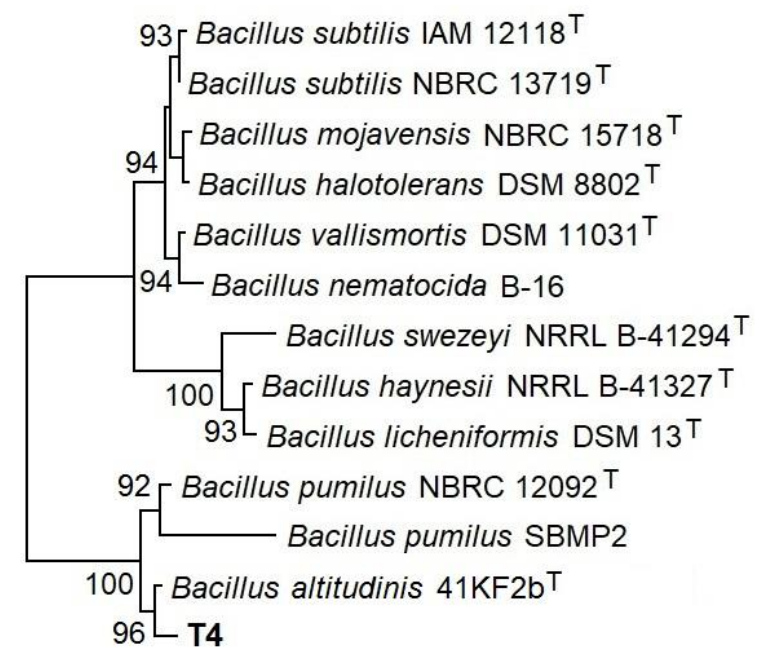

$\widehat{0.005}$

Figure 4. Neighbor-joining phylogenetic tree based on 16S rDNA showing the distance of T4 with reference isolates

The chemical changes in rotting tuber is due to active metabolism of pathogen bacteria. Bacteria secrete amylase to break down the starch in tuber [18], of which a fresh porang tuber contains $15.7 \%$ [19]. Starch is broken down to maltose, maltose subsequently is hydrolized to glucose.

Glucose is further metabolized by bacteria into pyruvic acid through glycolysis. The pyruvic acid can be either metabolized aerobically or anaerobically. The aerobic pathway ends in TCA cycle, whereas the anaerobic pathway ends in the conversion of acetaldehyde to ethyl alcohol or ethanol [18]. These explanations support the result of this study that the reducing sugar and ethanol content is higher in tubers infected with bacteria than in control tubers (C) (Figure 2 and 3).

Even so, just like other plant materials, tubers

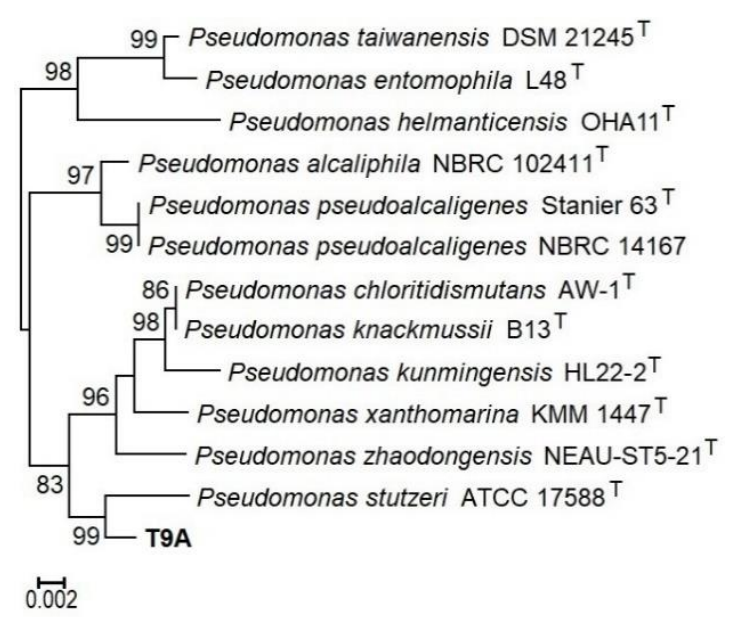

Figure 5. Neighbor-joining phylogenetic tree based on 16S rDNA showing the distance of isolate T9A with reference isolates.

naturally contain sugars such as fructose, sucrose, cellobiose, rhamnose and mannitol [18]. This explains the reducing sugars present in control tubers (C) (Figure 2). It is possible that the ethanol present in control tubers (C) (Figure 3) was due to the low amount of oxygen inside the culture bottle during incubation. There has been a report of endogenous ethanol accumulation in potato tubers under anaerobic condition [20].

\section{Identification of potential pathogen bacteria}

Isolate T4 had 99.7\% 16S rDNA sequence similarity with Bacillus altitudinis strain 41KF2b (Figure 4). Isolate T9A had 99.1\% 16S rDNA sequence similarity with Pseudomonas stutzeri strain ATCC 17588 (Figure 5). Genus Bacillus and Pseudomonas are known to be saprophytic bacteria that are commonly present on tubers [7]. Bacillus and Pseudomonas are some of the dominant groups accompanying Pectobacterium atrosepticum during the rotting of potato tubers [21]. Both genera are known as commensals, nonpathogenic microbes, that invade the the intracellular space of the host, but are usually dormant. However, once the tubers are infected with pectinolytic bacteria like Pectobacterium spp., they began to flourish during the rotting process [21].

So far, B. altitudinis has been reported as a soft rot agent in apples and pears [22]. Although the information about pathogenicity of B. altitudinis is still limited, there are several reports of other closely-related Bacillus species as soft rot agent, 
such as B. pumilus in potato [23], ginger [24] and melon [25], B. polymyxa in garlic [26], and B. amyloliquefaciens in potato [27].

$P$. stutzeri isolated from spoilt orange has the ability to produce pectinase [28]. P. stutzeri has a relatively high conversion rate of starch [29]. This explains the high reducing sugar content in tubers infected with isolate T9A. P. stutzeri is known to cause brown spot disease in oyster mushroom [30]. Other Pseudomonas species thet could cause soft rot, such as $P$. cichorii and $P$. maculicola in cruciferous vegetables [18], $P$. marginalis in potato [31] and tuber of Zantedeschia spp. which are from the same family as porang [32], P. aeruginosa in onion [33] and ginseng [34], and $P$. viridiflava in tomato [35].

\section{Conclusion}

Bacterial isolates from porang tubers that have the highest potency to cause rotting on porang tubers were T4 and T9A, which were identified as Bacillus altitudinis and Pseudomonas stutzeri, respectively. Both genera have the ability to break down tuber starch into sugars and ferment sugars into ethanol and act as opportunistic pathogen of tuber rot.

\section{Acknowledgment}

This research was financially supported by DPPM/DIKTI Research Grant 2018, Faculty of Mathematics and Natural Sciences, Brawijaya University.

\section{References}

1. Mekkerdchoo O, Borompichaichartkul C, Perrigo A et al. (2016) Tracing the Evolution and Economic Potential of Konjac Glucomannan in Amorphophallus species (Araceae) using Molecular Phylogeny and RAPD Markers. Phytotaxa 282 (2): 81. doi: 10.11646/phytotaxa.282.2.1

2. Santosa E, Susila AD, Lontoh AP et al. (2016) NPK Levels and Application Methods on Productivity of Amorphophallus muelleri Blume in Intercropping System. Jurnal Jamu Indonesia 1 (2): 1-8. doi: 10.29244/jji.v1i2.12.

3. Dwiyono K, Sunarti TC, Suparno O, Haditjaroko L (2012) Patchouli Alcohol Enrichment From Patchouli Oil Using Molecular Distillation Unit. Journal of Agroindustrial Technology 24 (3): 179-188.

4. Nourian F, Kushalappa AC, Ramaswamy HS (2002) Physical, Physiological and Chemical Changes in Potato as Influenced By Erwinia Carotovora Infection. Journal of Food Processing and Preservation 26 (5): 339-359. doi: 10.1111/j.1745-4549.2002.tb00489.x.

5. Wu J, Yang C, Jiao Z et al. (2015) Genetic Relationships of Soft Rot Bacteria Isolated from Konjac in China by Amplified Fragment Length Polymorphism (AFLP) and 16S rDNA Gene Sequences. Agricultural Sciences 06 (07): 717-723. doi: 10.4236/as.2015.67069.

6. He F, Duan J, Luo B et al. (2013) Pathogenic bacteria biodiversity of Amorphophallus infected with soft rot disease in Langao,Shaanxi. Journal of Northwest A \& F University(Natural Science Edition) 41 (7): 91-98.

7. Pérombelon MCM (2002) Potato diseases caused by soft rot erwinias: an overview of pathogenesis. Plant Pathology 51 (1): 1-12. doi: 10.1046/J.00320862.2001.SHORTTITLE.DOC.X.

8. Waterer DR, Pritchard MK (1985) Production of volatile metabolites in potatoes infected by erwinia carotovora var. carotovora and e. carotovora var. atroseptica. Canadian Journal of Plant Pathology 7 (1): 47-51. doi: 10.1080/07060668509501513.

9. Kesaulya H, Baharuddin, Zakaria B, Syaiful SA (2015) Isolation and Physiological Characterization of PGPR from Potato Plant Rhizosphere in Medium Land of Buru Island. Procedia Food Science 3 190-199. doi: 10.1016/J.PROFOO.2015.01.021.

10. Arfani N, Azrianingsih R, Suharjono S, Suharjono S (2018) Isolation and Identification of Antagonistic Bacterium against a Pathogens of Bacterial Tuber Rot of Amorphophallus muelleri. The Journal of Experimental Life Sciences 8 (3): 165-172. doi: 10.21776/ub.jels.2018.008.03.06.

11. Sakaroni R, Suharjono S, Azrianingsih R (2019) Identification of potential pathogen fungi which cause rotten on Porang (Amorphophallus muelleri Blume) tubers. In: AIP Conf. Proc. AIP Publishing LLC . p 080010.

12. Ikanone CEO, Oyekan PO (2014) Effect of Boiling and Frying on the Total Carbohydrate, Vitamin C and Mineral Contents of Irish (Solanun tuberosum) and Sweet (Ipomea batatas) Potato Tubers. Nigerian Food Journal 32 (2): 33-39. doi: 10.1016/S0189-7241(15)30115-6.

13. Sayyad SA, Chaudhari SR, Panda BP (2015) Quantitative determination of ethanol in arishta by using UV-visible spectrophotometer. Pharmaceutical and Biological Evaluations 2 (5): 204-207.

14. Naveed M, Mubeen S, khan S et al. (2014) Identification and characterization of rhizospheric microbial diversity by 16 S ribosomal RNA gene sequencing. Brazilian Journal of Microbiology 45 (3): 985-993. doi: 10.1590/S1517-83822014000300031. 
15. Mohkam M, Nezafat N, Berenjian A et al. (2016) Identification of Bacillus Probiotics Isolated from Soil Rhizosphere Using 16S rRNA, recA, rpoB Gene Sequencing and RAPD-PCR. Probiotics and Antimicrobial Proteins 8 (1): 8-18. doi: 10.1007/s12602-016-9208-z.

16. Wakil SM, Oyinlola KA (2011) Diversity of pectinolytic bacteria causing soft rot disease of vegetables in Ibadan, Nigeria. Journal of Applied Biosciences 38 2540-2550.

17. Benada M, Boumaaza B, Boudalia S et al. (2018) Variability of aggressiveness and virulence of Erwinia carotovora subsp. carotovorum causing the soft rot on potato tubers in the western of Algeria. Int J Plant Biol. doi: 10.4081/pb.2018.7568

18. Tournas VH (2005) Spoilage of Vegetable Crops by Bacteria and Fungi and Related Health Hazards. Critical Reviews in Microbiology 31 (1): 33-44. doi: 10.1080/10408410590886024.

19. Rokhmah DN, Supriadi H (2015) Prospek Pengembangan Iles-Iles (Amorphophallus muelleri Blume) sebagai Upaya Diversifikasi Pangan di Indonesia. SIRINOV 3 (1): 1-10.

20. Claassens MMJ, Verhees J, van der Plas LHW et al. (2005) Ethanol breaks dormancy of the potato tuber apical bud. Journal of Experimental Botany 56 (419): 2515 2525. doi: 10.1093/jxb/eri245.

21. Kõiv V, Roosaare M, Vedler E et al. (2015) Microbial population dynamics in response to Pectobacterium atrosepticum infection in potato tubers. Scientific Reports 5 (1): 11606. doi: 10.1038/srep11606.

22. Elbanna K, Elnaggar S, Bakeer A (2014) Characterization of Bacillus altitudinis as a New Causative Agent of Bacterial Soft Rot. Journal of Phytopathology 162 (1112): 712-722. doi: 10.1111/jph.12250.

23. Bathily H, Babana AH, Samaké F (2010) Bacillus pumilus, a new pathogen on potato tubers in storage in Mali. African Journal of Microbiology Research 4 (20): 2067-2071.

24. Peng Q, Yuan Y, Gao M (2013) Bacillus pumilus, a Novel Ginger Rhizome Rot Pathogen in China. Plant Disease 97 (10): 1308-1315. doi: 10.1094/PDIS-12-121178-RE.

25. Song JH, Wu ZR, Zhang LX et al. (2018) First Report of Bacillus pumilus Causing Fruit Rot on Muskmelon ( $\mathrm{Cu}$ cumis melo ) in China. Plant Disease 102 (2): 439-439. doi: 10.1094/PDIS-08-17-1169-PDN.

26. Galal AA, Abdel-Gawad TI, El-Bana AA (2002) Postharvest decay of garlic cloves caused by Bacillus polymyxa and Fusarium moniliforme. Egypt Journal of Microbiology 36: 71-88.

27. Wang L, Li XB, Suo HC et al. (2017) Soft rot of potatoes caused by Bacillus amyloliquefaciens in Guangdong province, China. Canadian Journal of Plant Pathology 39 (4): 533-539. doi: 10.1080/07060661.2017.1381994.

28. Muslim DSN, Hasan AM, Mahdi NZ (2016) Antibiofilm and antiadhesive properties of pectinase purified from Pseudomonas stutzeri isolated from spoilt orange. Advances in Environmental Biology 10 (11): 91-99.

29. Schmidt J, John M (1979) Starch metabolism in Pseudomonas stutzeri. I. Studies on maltotetraose-forming amylase. Biochimica et Biophysica Acta (BBA) - Enzymology 566 (1): 88-99. doi: 10.1016/0005-2744(79)902523.

30. Mallesha BC, Shetty KS (1988) A New Brown Spot Disease of Oyster Mushroom Caused by Pseudomonas stutzeri. Current Science 57 1190-1192. doi: 10.2307/24090888.

31. Li J, Chai Z, Yang H et al. (2007) First report of Pseudomonas marginalis pv. marginalis as a cause of soft rot of potato in China. Australasian Plant Disease Notes 2 (1): 71. doi: 10.1071/DN07029.

32. Krejzar V, Mertelík J, Pánková I et al. (2008) Pseudomonas marginalis associated with soft rot of Zantedeschia spp. Plant Protection Science 44: 85-90. doi: 10.17221/16/2008-PPS.

33. Abd-Alla MH, Bashandy SR, Ratering S, Schnell S (2011) First report of soft rot of onion bulbs in storage caused by Pseudomonas aeruginosa in Egypt. Journal of Plant Interactions 6 (4): 229-238. doi: 10.1080/17429145.2010.535618.

34. Gao J, Wang Y, Wang CW, Lu BH (2014) First report of bacterial root rot of ginseng caused by Pseudomonas aeruginosa in China. Plant Disease 98 (11): 1577. doi: 10.1094/PDIS-03-14-0276-PDN.

35. Saygili H, Sahin F, Sahin F et al. (2005) New symptoms of tomato soft rot diseases in Turkey. Acta Horticulturae 695: 291-294. doi: 10.17660/ActaHortic.2005.695.32. 